\title{
UJI AKTIVITAS EKSTRAK ETANOL DAUN KARAMUNTING (Rhodomyrtus tomentosa.) TERHADAP PERTUMBUHAN BAKTERI Salmonella thypi
}

\author{
Suci Wulandari ${ }^{1}$, Chandra Pranata ${ }^{2}$, Yanna Rotua Sihombing ${ }^{3}$, \\ Muhammad Hamim Nasution. \\ Institut Kesehatan Medistra Lubuk Pakam, Jalan Sudirman No.38 \\ Lubuk Pakam \\ e-mail: sucici19@gmail.com \\ DOI : https://doi.org/10.35451/jfm.v2i2.382
}

\begin{abstract}
:
Salmonella thypiis a bacterium that causes typhoid fever. Typhoid fever is an infectious disease that is still a health problem, especially in Indonesia. There are several studies on the types of plants that can control bacterial growth. Indonesian plants are often used as medicine, one of which is the karamunting (Rhodomyrtus tomentosa.). Traditionally a number of parasitic species have been used to prevent and treat various diseases such as cough, anticancer, diuretic, anti-inflammatory, antibacterial, wound or infection karamunting (Rhodomyrtus tomentosa.) Has active compounds such as flavonoids, alkaloids, tannins, saponins, and glycosides which have antibacterial abilities. The purpose of this study is to determine the inhibition of extract of karamunting (Rhodomyrtus tomentosa.) at concentrations of 5\%,10\%, and 15\%. Test samples using Salmonella thypi. This research is an experimental study with a design (posttest). The research methods included the collection of plant material, determination of plant material, making simplicia, phytochemical screening, making ethanol extract from simplicia by maceration, testing chemical compound groups, and antibacterial testing with paper disk diffusion methods. Karamunting is extracted by maceration process, using $70 \%$ ethanol solvent. The results of this study indicate that the benalu coffee leaf extract (Rhodomyrtus tomentosa.) has inhibitory capacity as an antibacterial in Salmonella thypi with a mean inhibition of $16.87 \mathrm{~mm}$ at a concentration of $5 \%, 17.24 \mathrm{~mm}$ at a concentration of $10 \%$, and $18.21 \mathrm{~mm}$ at a concentration of $15 \%$. The greatest inhibition is produced at a concentration of $15 \%$, because the higher the concentration of the extract, the higher the diameter of the inhibition produced, because the more active substances contained in the extract.
\end{abstract}

Keywords : karamunting leaf extract (Rhodomyrtus tomentosa.), Salmonella thypi, inhibitory power. 


\section{PENDAHULUAN}

World Health Organization (WHO) memperhatikan ada total 10 miliar infeksi baru di seluruh dunia setiap tahun. Jumlah korban di seluruh dulia akibat infeksi adalah sekitar 13 juta orang per tahun (Cowan, 2012).

$\begin{array}{llr}\text { Infeksi } & \text { suatu } & \text { penyakit } \\ \text { disebabkan } & \text { oleh } & \text { berbagi }\end{array}$
mikroorganisme seperti virus, jamur, riketsia, protozoa, dan bakteri Penyakit infeksi akibat bakteri merupakan salah satu masalah sebar tidak saja di indonesia, tetapi juga di seluruh dunia. Bakteri patogen yang sering menyebabkan infeksi pada saluran cerna manusia (Nursidika dkk., 2014). Sejak zaman dahulu masyarakat Indonesia mengetahui dan memanfaatkan tanaman yang berkhasiat sebagai obat, salah satu upaya dalam penanggulangan malasah kesehatan yang dihadapinya. Pengetahuan tentang pemanfaatan tanaman ini adalah suatu budaya bangsa dari pengetahuan empiris, pengetahuan, dan pengetahuan yang diberikan secara turun temurun diwariskan kepada generasi ke generasi berikutnya Menurut hasil (Riskesdas tahun 2013), sebesar 30,4\% masyarakat di indonesia memanfaatkan pelayanan kesehatan tradisional dalam satu tahun terakhir dan 49\% diantaranya menggunakan obat ramuan tradisional (Kemenkes RI, 2013).

Indonesia merupakan nagara beriklim tropis yang terkenal akan kekayaan alamnya dengan berbagai macan flora yang dapat didapatkan dan tentunya memiliki beberapa manfaat, salah satunya yaitu sebagai tanaman obat. Saat ini bahan alam telah banyak dimanfaatkan baik sebagai obat maupun tujuan lain atau yang dikenal dengan isrilah back to nature (kembali ke yang alami). Bahan alam yang dimanfaatkan sebagai obat memiliki efek samping sedikit kecil dari pada obat kimia sehingga obat tradisional seperti yang berasal dari tanaman lebih aman dikonsumsi dari pada obat kimia (Ningsih dkk., 2014).

Kandungan senyawa aktif dalam tanaman merupakan bahan penting produksi obat dengan efek terapeutik. Tanaman obat memiliki beberapa kandungan metabolit sekunder seperti flavonoid, glikosida, tanin, minyak atsiri, dan senyawa aktif lainnya yang memiliki efek terapeutik, salah satunya yaitu sebagai antimikrobia. Senyawa antibakteri yang disiapkan untuk menangani tingkat persebaran mikroorganisme dalam jangka waktu pendek (Ramproshad dkk., 2012).

Salah satu tumbuhan yang berkhasiat obat, dikenal dan digunakan masyarakat adalah tumbuhan karamunting (Rhodomyrtus tumentosa) dari Bangka Belitung. Menurut pengalaman masyarakat Desa Saitnihuta, Kecamatan Dolok Sanggul, Kabupaten Humbang Hasundutan, Provinsi Sumatera Utara, daun karaminting dapat digunakan sebagai obat luka dengan cara mengunyah dan ditempelkan di tempat luka. Daun tumbuhan ini secara tradisional berkhasiat mengobati keputihan, cacingan pada anak-anak, diare, bisul, luka berdarah dan luka bakar. (Djauhariya,2004).

Berdasarkan penelitian pendahuluan (Retnaningstya dan Mulyani, 2008), ekstrak etanol daun karamintung dengan konsentrasi 5$25 \%$ memiliki aktivitas antibakteri dengan diameter zona hambatan sebesar 17,44-23,99 mm terhada, serta memiliki aktivitas penghambatan yang kuat hingga sangat kuat terhadap pertumbuhan beberapa bakteri lain 
seperti StayphiBacillus subtilis, Shigela dysentriae, dan juga melaporkan bahwa ekstrak aseton daun Karamunting memiliki aktivitas antibakteri terhadap B.cereus. Daun Karamunting memiliki kandungan senyawa golongan tanin terhidrolisis yaitu Nobotanin B yang memiliki aktivitas antibakteri terhadap Helicobacter pylori (Hsu, 2007).

Tumbuhan karamunting adalah termasuk familli Myrtaceae (suku jambu-jambuan). karamunting adalah sejenis tanaman liar dengan pohon berkayu. Di padang-padang terbuka tingginya hampir setinggi orang dewasa (tingginya dapat mencapai 4 meter). Daunnya keras, panjang 5-7 cm dan luasnya $2-3,5 \mathrm{~cm}$, oval, ujungnya dari tumpul sampai dengan tajam, di atas hijau mengkilap, dibawah lebih abuabu. Bunganya tersembunyi atau dalam 2 atau 3 kelompok. Buahnya dapat dimakan, panjang $10-15 \mathrm{~mm}$, berwarna ungu hitam (Sutomo dkk, 2010).

Demam tifoid merupakan penyakit infeksi akut pada usus halus dengan gejala demam satu minggu atau lebih disertai gangguan pada saluran pencernaan (Widodo, 2007). Di Jawa Timur kejadian demam tifoid, di Puskesmas dan beberapa Rumah Sakit masing masing 4000 dan 1000 kasus per bulan, dengan angka kematian $0,8 \%$. Hasil penelitian terdahulu di Surabaya menunjukkan bahwa penyakit demam tifoid diperkirakan dari tahun ke tahun cenderung meningkat. Di RSUD Dr. Soetomo Surabaya selama periode 1991-1995 telah dirawat 586 penderita demam tifoid dengan angka kematian $1,4 \%$, dan selama periode 1996-2000 telah dirawat 1563 penderita demam tifoid dengan angka kematian 1,09\% (Soewandojo et al., 2007), sedangkan prevalensi demam tifoid di Kabupaten Malang sebanyak $1,2 \%$ dari 10.966 sampel pada tahun
2007 (Departemen Kesehatan Jawa Timur, 2008).

Infeksi adalah proses invasi dan pembiakan mikroorganisme yang terjadi di jaringan tubuh manusia yang secara klinis mungkin tidak terlihat atau dapat menimbulkan cedera seluler lokal akibat kompetisi metabolisme, toksin, replikasi intrasel atau respon antigen-antibodi (Dorlan,2002). Infeksi yang disebabkan oleh jamur semakin meningkat dan banyak obat yang mengalami resistensi. Bakteri yang paling sering menyebabkan penyakit salah satunya Salmonella thypi. Berdasarkan hal tersebut maka diperlukan penelitian untuk mendapatkan obat antibakteri alternatif.

Salmonella thypi (S. typhi) merupakan kuman pathogen penyebab demam tifoid, yaitu suatu penyakit infeksi sistemik dengan gambaran demam yang berlangsung lama, adanya bakteri disertai inflamasi yang dapat merusak usus dan organ-organ hati (Girgis et al., 1999). Demam tifoid merupakan penyakit menular yang tersebar di seluruh dunia, dan sampai sekarang masih menjadi masalah kesehatan terbesar di Negara sedang berkembang dan tropis seperti Asia Tenggara, Afrika dan Amerika Latin. Insiden penyakit ini masih sangat tinggi dan diperkirakan sejumlah21 juta kasus dengan lebih dari 700 kasus berakhir dengan kematian.

Salmonella typhi menyebar secara fekal-oral melalui makanan ataupun minuman.Salmonella typhi mampu hidup dalam air, sampah kering debu dan apabila bakteri ini hidup ditempat hidup yang cocok maka bakteri berkembang biak mencapai dosis infektif. Tentunya perlu diperhatikan faktor kebersihan lingkungan, pembuangan sampah, dan klorinasi air minum. Masa inkubasi demam tifoid berlangsung antara 10- 
14 hari. Demam ini ditandai dengan gejala demam lebih dari seminggu, lidah kotor, muntah, diare, pusing, lemas dan pingsan (Farhan, 2009).

Suatu zat yang diduga mampu menghambat aktivitas bakteri disebut antibakteri. Salah satu herbal yang digunakan adalah ekstrak etanol karamunting yang menurut peneliti sebelumnya berpotensi sebagai diduga memiliki aktivitas antibakteri (Artanti et al, 2009).

karamunting adalah tumbuhan, yang awalnya dianggap tumbuhan yang merugikan karena merusak tanaman komersial.Namun benalu berpotensi sebagai ramuan obatobatan. Secara tradisional beberapa spesies benalu sejak zaman dahulu telah digunakan untuk mencegah dan mengobati berbagai penyakit antara lain sebagai obat batuk, antikanker, diuretik, antiradang, antibakteri, luka atau infeksi (Anita et al, 2014).

Bagian benalu yang banyak dimanfaatkan sebagai obat adalah daunnya.Kandungan kimia yang terdapat pada daun benalu kopi antara lain flavonoid, tanin, alkaloid, dan saponin yang memiliki aktivitas antibakteri serta antioksidan (Artanti et al, 2009; Davehat et al, 2002).

Salah satu Provinsi dengan penghasil kopi terbesar di Indonesia adalah Provinsi Aceh, yang tepatnya didaerah dataran tinggi gayo, ada berbagai jenis tanaman kopi yang tumbuh di daerah tersebut, selama ini pemanfaatan tanaman kopi secara komersial hanya terfokus pada pengolahan biji kopi sebagai minuman seduh maupun bahan tambahan makanan. Benalu kopi merupakan tumbuhan parasit pada inang kopi yang dapat merusak tanaman inangnya. Masyarakat dataran tinggi gayo memanfaatan benalu kopi sebagai obat tradisional untuk penyembuhan berbagai penyakit dengan cara merebus daun benalu kopi yang sudah kering dan meminum hasil rebusan tersebut (Raja, 2008).

\section{METODE}

\section{Rancangan Penelitian}

Jenis penelitian ini adalah penelitian eksperiment murni (true experiment) dengan rancangan postest dengan kelompok kontrol (postest only control group design).

Pada metode penelitian ini meliputi pengumpulan bahan tanaman, determinasi bahan tanaman, pembuatan simplisia, skrining fitokimia, pembuatan ekstrak etanol dari simplisia secar amaserasi, pengujian golongan senyawa kimia terhadap simplisia dari daun karamunting selanjutnya pengujian aktivitas antibakteri dengan metode difusi menggunakan kertas cakram. Parameter yang diambil adalah besarnya diameter hambat pertumbuhan bakteri.

\section{Lokasi Pelaksanaan Penelitian}

Penelitian ini dilakukan dibeberapa tempat:

1. Laboratorium Botani Fakultas Farmasi Institut Kesehatan Medistra Lubuk Pakam untuk membuat simplisia daun karamunting.

2. Laboratorium Kimia Organik Fakultas Farmasi Institut Kesehatan Medistra Lubuk Pakam untuk membuat ekstrak dari simplia yang sudah dikeringkan.

Laboratorium Mikrobiologi RS Grandmed Lubuk Pakam untuk membuat biakan bakteri yang akan digunakan untuk penelitian.

Alat

Blender, Kertas perkamen, Lemari pengering, Timbangan, Batang pengaduk, Beaker glass, Kertas saring, 
Rotary evaporator, Timbangan analitik, Spatula, Laminary air flow, Autoklaf, Tabung reaksi, Rak tabung reaksi, Erlemeyer, Gelas ukur, Pendopol, Cawan petri, Jarum ose, Oven, Inkubator, Kompor gas, Kulkas, Bunsen, Pipet tetes, Jangka sorong, Lemari pendingin, Mikroskop, Kertas cakram, Penjepit tabung, Desikator dan pipet mikro.

\section{Bahan}

Daun Karamunting, Etanol 70\%, $\mathrm{FeCl}_{3} 10 \%, \mathrm{HCl} 0,2 \mathrm{~N}$, Larutan Iodium, Pereaksi Mayer, Aquadest, Bakteri Salmonella thypi, $\mathrm{NaCl}$ 0,9\%, Nutrient agar.

\section{Pembuatan Ekstrak}

Sampel daun karamunting yang telah kering sebanyak $500 \mathrm{~g}$ diblender sampai menjadi serbuk simplisia, kemudian direndam dengan etanol $70 \%$. Campuran tersebut diaduk kuat sampai menjadi homogen, kemudian didiamkan selama 5 hari ditempat yang sejuk dan terlindung dari cahaya sambil beberapa kali diaduk. Hasil dari maserasi tersebut disaring dengan kain flanel, hasil dari maserasi tersebut merupakan filtrat, kemudian ditampung digelas beaker sedangkan ampasnya di maserasi lagi dan dilanjutkan dengan langkah yang sama. Selanjutnya filtrat pertama dan filtrat kedua digabungkan menjadi satu dan kemudian dipekatkan dengan rotary evaporatorsampai etanol habis menguap dan hanya sisa ekstrak berair saja.Selanjutnya kandungan air yang ada dihilangkan dengan memanaskannya diatas penangas air (water bath), suhu dijaga kurang dari $60^{\circ} \mathrm{C}$ agar tidak merusak kandungan

\section{HASIL DAN PEMBAHASAN}

\section{Uji Skrining Fitokimia Hasil Pemeriksaan Karakteristik}

Hasil pemeriksaan secara makroskopik yang dilakukan terhadap daun karamunting yaitu permukaan atas halus dan berwarna hijau, permukaan bawah berwarna hijau lemah. Hasil makroskopik bentuk dari benalu kopi yaitu akar berbentuk ramping, menjalar pada inangnya dan berwarna kusam. Batang tumbuhan panjang tegak berwarna hijau kusam. Daun bentuk lonjong kecil-kecil yang memiliki warna hijau tua sedikit kasar permukaannya. Terdapat biji kecil-kecil disela-sela tangkai daun dan batang, biji berbentuk kecil seperti isi pensil, memiliki sungut pendek.

Hasil karakterisasi ekstrak etanol daun benalu kopi (Loranthus ferrugineus Roxb.) memenuhi syarat berdasarkan persyaratan pada Materia Medika Indonesia (MMI) edisi VI yang mencantumkan kadar air tidak lebih dari $10 \%$, sedangkan kadar airekstrak etanol daun daun benalu kopi (Loranthus ferrugineus Roxb.) yang diperoleh adalah $9,46 \%$. Pemeriksaan kadar air penting untuk mengetahui kandungan air dalam ekstrak etanoldaun Benalu kopi, khususnya yang mudah mengabsorpsi air dan zat aktif yang terdapat pada ekstrak etanol yang kental membusuk akibat kadar air yang tinggi. Kadar air yang tinggi akan meningkatkan pertumbuhan bakteri dan jamur (WHO, 1992).

Hasil pemeriksaan karakteristik daun karamunting dapat dilihat pada tabel dibawah ini.

\begin{tabular}{llcc}
\hline NO & & \multicolumn{2}{c}{ Ekstrak } \\
\cline { 3 - 4 } & Penetapan & $\begin{array}{c}\text { Kadar } \\
(\%)\end{array}$ & $\begin{array}{c}\text { Persyaratan } \\
\text { (MMI) }\end{array}$ \\
1 & Kadar air & 9,46 & $\leq 10$ \\
2 & $\begin{array}{l}\text { Kadar sari } \\
\text { larut dalam } \\
\text { air }\end{array}$ & 13,7 & $\geq 16$ \\
& $\begin{array}{l}\text { Kadar sari } \\
\text { larut dalam } \\
\text { etanol }\end{array}$ & 7,80 & $\geq 6$ \\
& $\begin{array}{l}\text { Kadar abu } \\
\text { total }\end{array}$ & 5,70 & $\leq 9$ \\
\hline
\end{tabular}




5 \begin{tabular}{lll}
\hline $\begin{array}{l}\text { Kadar abu } \\
\text { tidak larut } \\
\text { dalam asam }\end{array}$ & 0,54 & $\leq 1$ \\
\hline
\end{tabular}

\section{KESIMPULAN DAN SARAN}

\section{KESIMPULAN}

1. Ekstrak etanol daun karamunting memiliki kandungan senyawa kimia yang sama yaitu alkaloid, flavonoid, tannin, saponin, dan glikosida.

2. Rerata daya hambat ekstrak etanol daun karamunting sebgai antibakteri terhadap S. Thypi PASpada konsentrasi $5 \%$ adalah $16,87 \mathrm{~mm}$

3. Rerata daya hambat ekstrak etanol daun karamunting sebagai antibakteri S. Thipy pada konsentrasi $10 \%$ adalah $17,24 \mathrm{~mm}$

4. Rerata daya hambat ekstrak etanol daun karamunting sebagai antibakteri S. Thypi pada konsentrasi $15 \%$ adalah $18,21 \mathrm{~mm}$

5. Konsentrasi terbaik ekstrak etanol daun karamunting sebagai antibakteri terhadap S. Thypi adalah konsentrasi $15 \%$.

\section{DAFTAR PUSTAKA}

\section{Jurnal :}

Artanti, N., Jamilah, dan Hartati, S.(2009).Laporan Teknis Sub Tolok Ukur Pengembangan Senyawa Potensial antikanker dari Taxus sumatrana dan Benalu. Serpong: Puslit Kimia LIPI..

Departemen Kesehatan RI. 2000. Pedoman Pelaksanaan Usaha Kesehatan Gigi Sekolah. Direktorat Jendral Pelayanan Medik, Direktorat Kesehatan Gigi : Jakarta.
Azhari., I.L. (2014). Aktivitas Antimikroba Ekstrak Daun Kunyit (Curcuma Domestica Val.) Terhadap Escherichia coli, Staphylococcus aureus, Shigella dysenteriae, dan Lactobacillus acidophilus. Universitas Sumatera Utara.

Azmi, J. (2006). Penentuan Kondisi Optimum Fermentasi Aspergillus oryzae Untuk Isolasi Enzim Amilase Pada Medium Pati Biji Nangka (Arthocarphus heterophilus Lmk). Jurnal Biogenesis. 2(2): 55-58.

Cowan,ST. (2012). Manual for the Identification of Medical Bacteria. Cambridge University Press. London.

Depkes RI. (2006). Parameter StandarUmumEkstrakTumbuhan Obat.CetakanPertama. Jakarta :Depkes RI. Hal.10-11.

Difeo. (1953). Difco Manual of Dehydrated Culture Media and Reaggents For Microbiological and Clinical Laboratory Procedures. Difco laboratories.

Ditjen POM. (1979). Farmakope Indonesia.EdisiKetiga. Jakarta: DepartemenKesehatan RI. Hal. 33.

Ditjen POM. (1995). MateriaMedika Indonesia.Jilid VI. Jakarta:DepartemenKesehatanRI. Hal 896, 898.

Dorlan, W.A. Newman, (2002), KamusKedokteran.

AlihbahasaHuriwati Hartono, dkk., Edisi 29. Jakarta: EGC.

Dwidjoseputro. (1994). Dasar-Dasar Mikrobiologi. Djambatan. Jakarta.Fardiaz., S. (1992).MikrobiologiPangan I. Jakarta: PT. Gramedia Pustaka Umum.

Farnsworth, N.R. (1966). Biological and Phytochemical Screening of Plants.Journal of Pharmaceutical Sciences, Chicago: Reheis 
Chemical Company 55(3): 263264.

Girgis,N.I.,Butler, T., and Frenk, R. (1999).Azithromycin versus Ciprofloxacin for Treatment of Uncomplicated Thyphoid Fever in A Randomized Trial in Egypt That Included Patients with Multidrugresistance. Antimicrob. Agents and Chemother.43:14411444.

Nursidika Perdina, Saptarini O., Rafiqua N. (2014). Aktivitas Antimikroba Fraksi Ekstrak Etanol Buah Pinang ( Areca catechu L) pada Bakteri Methicilin Resistant Staphylococcus aureus. MKB Volume 46 No.2 